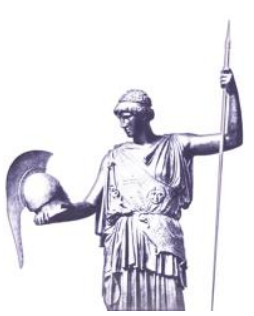

Research Article
Connections: The Quarterly Journal

ISSN 1812-1098, e-ISSN 1812-2973

\title{
Britain and the Common Security and Defense Policy of the European Union
}

\section{Irina Tsertsvadze}

Ministry of Defense, Georgia, https://mod.gov.ge/en

\begin{abstract}
This article analyzes Britain's position towards the Common Security and Defense Policy (CSDP) of the European Union from 1998 to 2016. It considers the reasoning for Britain's position toward CSDP through posing the research question: Why did Britain backed the launch of the CSDP and then not consistently support all its developments? Using a case study approach, it concentrates on the main developments of the CSDP, which are: launch of the CSDP (1998-1999); development of the operational headquarters (2010-2011); role of Britain in the Libyan crisis, which is not related to the institutional developments, but still is very important as the first real chance for the CSDP to be tested after its launch.

Through Putnam's Two-Level Game Theory, the article seeks to support the twin hypotheses that domestic affairs influence Britain's decisions towards CSDP, and that developments within the European Union impact on Britain's position towards CSDP through the interplay with domestic factors.
\end{abstract}

Keywords: Security and defense policy, EU, Britain, game theory, national interest, CSDP.

\section{Introduction}

Every international negotiation can be considered as a 'game' on two levels and the struggle to achieve consensus - first between the domestic constituents and then to bargain the achieved consensus on the international level. This is the 
essence of Putnam's Two-Level Game Theory. ${ }^{1}$ At the domestic level, policy makers are trying to lobby their policies through the different political groups and, in seeking for power, they are looking to create different coalitions in order to pursue their policies. At the international level, negotiators are trying to minimize the risk of sacrificing domestic pressure and minimizing negative consequences of foreign developments. "Any [national] leader who fails to satisfy his fellow players at the domestic table risks being evicted from his seat," says Putnam. ${ }^{2}$

This article analyses the reasoning behind Britain's position toward the European Union's Common Security and Defense Policy (CSDP) prior to the Brexit decision by asking the question: "Why did Britain back the launch of the CSDP and then fail to consistently support all of its developments?" The answers will be found in the way that British domestic affairs influenced Britain's decisions towards CSDP, just as developments within the European Union impacted on Britain's position towards CSDP.

It appears that the decisions made by the British Government from 1998 to 2016 towards the CSDP were indeed influenced both by domestic politics and by the developments in the EU, as indicated by Putnam. Three concrete case studies give the examination structure and chronology. These are:

- Launching CSDP: Constructive role of UK (1998-1999)

- Operationalizing CSDP: UK blocking the Operational HQ (2010-2011)

- The role of Britain in the Libyan crisis (2011)

Depending on one's point of view, taken together, these studies show either different facets of British policy-making in the security and defense field, or a singular kind of inconsistency that led, eventually, to the Brexit decision and its aftermath.

\section{The Setting and Context}

CSDP is an unusual political phenomenon that does not fit easily into traditional international relations theories because of the grouping of sovereign states in an international subsystem. The main confusion comes with the collective decisionmaking over security and defense issues, which are commonly supposed to be the last thing that EU member states would give up within collective decision making. Jolyon Howorth, a leading scholar in the area of European security, describes the situation as follows: "The moves towards pooling that last bastion of 'sovereignty' - Security and Defence Policy-with all their limitations and

1 Robert D. Putnam, "Diplomacy and Domestic Politics: The Logic of Two-level Games," International Organization 42, no. 3 (Summer 1988): 427-460.

2 Putnam, "Diplomacy and Domestic Politics," 437. 
caveats, constitute a sea-change in the way the EU and its member states will henceforth relate to the outside world." 3

That may have been part of the UK's problems with CSDP but the beginning of the $21^{\text {st }}$ century has also been marked by an increase in geopolitical volatility. The Arab Spring, the unraveling of Libya and Syria, the rise of ISIS in Syria and Iraq, Russia's invasion in Georgia and Ukraine, the annexation of Crimea and the refugee crisis - all these suggested that new ways were necessary to ensure the security of members of the Europe Union. Currently, the EU needs to rethink the way it acts, its principles, interests and priorities. As EU's High Representative of the European Union for Foreign Affairs and Security Policy and Vice-President of the European Commission, Federica Mogherini pointed out, "In challenging times, a strong Union is one that thinks strategically, shares a vision and acts together. This is even more true after the British referendum." ${ }^{4}$ It is clear that the crises beyond the borders are challenging the EU and its CSDP. The policy is a post-Cold War phenomenon stemming from the 1992 Maastricht Treaty. ${ }^{5}$ The appearance of it has corresponded to a precise historical context: the integration of Western Europe.

In that context, British leaders have been in a dilemma, trying to adjust the balance between American and European interests, rather than giving the EU priority. As one commentator put it, "In the 1970s, they leaned too far the other way, entering the European Communities on disadvantageous terms. Since the 1980s they have increasingly leaned away from Europe again, renegotiating their financial contributions in 1984-85, opting out of the euro in 1992, joining the American invasion of Iraq in 2003, and now divorcing the EU altogether." 6 From this political discourse, one may assume that being pro-European has been mostly unpopular in Britain: if politicians wanted to survive domestic debate, they would criticize Brussels. "British ministers often oppose measures coming

3 David R. Smith, The EU Divided: Effects of Dissimilar National Foreign Policies on CSDP (New Haven, Connecticut: Yale University, Yale College, December 2, 2011), https://politicalscience.yale.edu/sites/default/files/files/Smith_Devin.pdf. Jolyon Howorth, "From Security to Defence: The Evolution of the CFSP," in The International Relations of the European Union, ed. Christopher Hill and Michael Smith (Oxford: Oxford University Press, 2005), 182.

4 "High Representative Mogherini presents EU Global Strategy for Foreign and Security Policy," EU Summit, Brussels, 2016, accessed November 20, 2016, https://eeas.europa.eu/headquarters/headquarters-homepage/7337/highrepresentative-mogherini-presents-eu-global-strategy-foreign-and-securitypolicy_en.

5 “Maastricht Treaty," February 7, 1992, accessed December 15, 2016, http://eurlex.europa.eu/legal-content/EN/TXT/?uri=uriserv\%3Axy0026.

6 Ian Morris, "A Brief History of Britain's Relationship, Starting in 6000 BCE," Harvard Business Review, Digital Article, June 24, 2016, accessed February 20, 2017, https://hbr.org/2016/06/a-brief-history-of-britains-relationship-with-europestarting-in-6000-bce. 
out of Brussels or other capitals because they fear the reaction of the British media or public." 7

The interaction is clear between the domestic and international politics as it applies to British policy towards the European Union's CSDP. This is the reason behind choosing the three case studies as illustrations: they best explain the positive, negative and in-between roles of Britain within the CSDP. All three of them underline different positions of Britain towards the institutional developments of the CSDP and thus give us ground to analyze the reasoning behind them. The launch of CSDP is historically the most important development of the concept; without Britain, it is hardly imaginable that it could happen. Developing a military-operational Headquarters for the EU could have been the second major event in the history of the CSDP, but it did not happen because Britain rejected the idea. Intervening in Libya in the 2011 crisis with an EU military force could have been the first ever real test for the policy, but EU opinions were divided. For Britain, the principal issue was a technical one - to be involved individually, bilaterally with France, or collectively through either the EU or NATO. Ideologically, France, the other big military power within the EU, was for a united and strong Europe relying on its own military capabilities. With the Libyan decision, domestic politics operated differently on security policy-making in London and Paris. In both cases, the Two-Level Game theory by Robert D. Putnam is a useful tool for analysis.

The heart of the theory is that international negotiations are characterized by simultaneous activities at the domestic and international levels. A national negotiating team seeks to maximize its state's international 'win-set,' in Putnam's phrase, and does so by constantly being aware of its own domestic inhibitions and constraints. Agreements internationally are therefore the outcome of overlaps between the win-sets of the states involved in the negotiations. For the three case studies here, this can be articulated in our case studies as following: for Tony Blair in 1998, without domestic support on his decision to help launch CSDP, it would be difficult to have achieved the win-set. For David Cameron ten years later, because he did not have support from the major political parties on establishing the Operational Headquarter of the EU, the win-set of the EU in this case could not be achieved.

\section{Application of the Two Level Game Theory to the Case Studies}

According to Robert D. Putnam, domestic politics is crucial in any kind of international negotiation theory. Power and preferences of the major political actors on the domestic level should be taken into account. If the big win-set is to be achieved on the international level, the chief negotiator needs to keep in mind that all the constituents at the internal level will take part in the ratification

7 Charles Grant, "Why Is Britain Eurosceptic," Essay, Center for European Reform, December 19, 2008, accessed February 28, 2017, http://www.cer.org.uk/publications/ archive/essay/2008/why-britain-eurosceptic. 
process on the domestic level. ${ }^{8}$ On the EU's level, this theoretical approach demonstrates that when the time of the decision-making comes, each member of the EU is thinking of the potential domestic consequences and less about the common good of the EU in general.

\section{Launching CSDP / Constructive Role of Britain (1998-99)}

After the end of the Cold War, the United States had other foreign policy priorities than guaranteeing the security of Western Europe. New security paradigms started to emerge. After the fall of the Berlin Wall, policy makers in Washington switched their attention to Asia, the Gulf and the Middle East, underlining the feeling that Europe was no longer a problem. The United States' approach was simple: European security had to be delivered by the Europeans themselves. Wars in Yugoslavia in the 1990s soon demonstrated the inability of the European Union to guarantee security on the continental Europe. This development made it obvious that the EU was in need of a permanent security and defense system on which it could rely.

Following the end of the Cold War, the idea of a Common Security and Defense Policy was announced after the introduction of the Common Foreign and Security Policy as the second pillar of the EU under the Maastricht Treaty. However, it was not implemented straight away. In fact, it was not until the Saint-Malo Summit in 1998 that it became a possibility.

It is well known that the Labour government that came to power in 1997 was distinctly more pro-European than any of its predecessors. "Tony Blair arrived strong and with a modernizing agenda that seemed to put Europe at the heart of Britain as much as the other way round." ${ }^{9}$ The most important aspect of Blair's European legacy is widely considered to be the Saint-Malo Summit where, together with the French President, Jacques Chirac, he tried to launch a real foreign and security policy for Europe. The Saint-Malo Summit in September 1998 ended with a declaration stressing the importance of the security dimension and that implementation machinery and the ability to deploy forces were essential for the EU's external policy.

This part of the case study very much strengthens the Putnam-related notion that domestic affairs influence Britain's decisions towards the Common Security and Defense Policy. However, the international level should not be ignored. Three issues were important at the time. The first was the dominant role of the USA in European defense; secondly, the aftermath of the wars in Yugoslavia; and, thirdly, the readiness within the EU itself to strengthen security and defense capabilities. Together they created an interplay between the domestic and international factors and pushed for a positive decision: in effect, a win-set both for

8 Putnam, "Diplomacy and Domestic Politics."

9 Simon Berlaymont, "Tony Blair and Europe," Open Democracy, free thinking for the world, May 30, 2007, accessed January 31, 2017, https://www.opendemocracy.net/ tony_blair_and_europe.jsp. 
Britain and EU. With the Saint-Malo declaration Britain, together with France, was aiming to transform the EU into a positive actor in the security field in Europe and for Europe by equipping itself with the kind of military capabilities so obviously absent during the recent Yugoslav conflicts.

The wording of the declaration, which Britain and France signed, was clear and demanding, saying: ".... The Union must have the capacity for autonomous action, backed up by credible military forces, the means to decide to use them, and a readiness to do so, in order to respond to international crises." ${ }^{10}$ For a number of scholars, this declaration did not outline the real intentions: "Even if Britain was so supportive of the European defense project after the Saint-Malo initiative with France in 1998, the British idea was more to lead than to participate. If various continentals got together and compensated for individual weakness by working together, then that was fine, but the UK itself would of course have no need to resort to such shifts." ${ }^{11}$ This is not surprising, having in mind the historical heritage of Britain as an empire, which did not believe in credible military partnerships with European countries. In addition, British Atlanticism and the 'special' relationship with the US gives the ground to some scholars to say that: "The US has consistently pressured the UK to become a full and active participant in all EU policy areas, including defense and security. That was one fundamental reason why Tony Blair went to Saint-Malo. If the UK found itself outside the EU, what could it offer the US in terms of security and defense." 12 Thus, it can be said that the position of the British decision makers-and of Tony Blair in particular-were very much influenced by the developments within the EU, especially the EU's desire itself to strengthen security and defense and on the broader international level when the US had become very much more interested in a strong EU responsible for the security of its borders.

To sum up the first case, it should be mentioned that the launch of the CSDP was not purely the result of developments within Britain or the EU. One can go even further and say that the major factor was the limited role of the United States in European security. Despite the fact that Tony Blair was the leader of the Labour Party, he was more enthusiastic towards the EU than anyone else was in the British Labour Party. Because of the changed political environment and the interplay of domestic and international factors, his policies in the office of the Prime Minister of Britain were different from previous governments. Blair

10 Joint Declaration issued at the British-French Summit, Saint-Malo, Foreign and Commonwealth Office of the United Kingdom, August 12, 2008, http://www.fco.gov.uk/ en/newsroom/latest-news/?view=News\&id=2244063.

11 Clara Marina O'Donnell, "Britain and France should not give up on EU defence cooperation," Policy Brief, Center for European Reform, October, 2011, accessed March 15, 2017, https://www.cer.org.uk/sites/default/files/publications/attachments/pdf/ 2011/pb_csdp_24oct11-3907.pdf.

12 Jolyon Howorth, "The CSDP without the UK: bad for Europe but even worse for Britain," in The Common Security and Defence Policy: National Perspectives, ed. Daniel Fiott (Brussels: The Royal Institute for International Relations, May 2015), 19, accessed March 15, 2017, http://aei.pitt.edu/64766/1/ep79.pdf. 
had no opposition to his taking the leading role in the CSDP. He very well understood what the US expected from Britain - to take the initiative within Europe in order to guarantee a strong partnership. Having concluded that it would be unacceptable for Britain to join the Euro Zone and the Schengen Agreement, he concentrated on the areas of security and defense. This was also in alignment with the historical British tradition of having a strong military force. However, looking at the Britain's role within CSDP almost 20 years afterwards, one can assume that the decision was more tactical than strategic, because very soon after that historical decision Britain isolated itself from the major institutional developments of the CSDP. The following case studies will consider further developments in the CSDP and Britain's role within it.

\section{Initial Development of the CSDP: UK Blocking the Operational HQ (2010-}

\section{1)}

The Lisbon Treaty, which was signed in 2007 and implemented in 2009, is about the establishment of a stronger and more focused central foreign policy with significantly upgraded tools at its disposal. The treaty moved away from the European Security and Defense Policy (ESDP) to CSDP. "According to the Lisbon Treaty, the role of the High Representative of the Union for Foreign Affairs and Security Policy has been bolstered in order to strengthen the EU's voice on the world stage. He will preside over the Foreign Affairs Council and will also be VicePresident of the Commission. A new European External Action Service will support the High Representative." ${ }^{13}$

The Lisbon Treaty introduced important provisions connected to the CSDP, including a mutual assistance and solidarity clause and the expansion of the Petersberg tasks. ${ }^{14}$ The creation of an Operational Headquarters (OHQ) became one of the major issues in the relationship between the EU and Britain after David Cameron's Conservative Party took office. For Catherine Ashton, the EU's High Representative for Foreign Affairs and Security Policy, the creation of the $\mathrm{OHQ}$ was closely connected to the implementation of the Lisbon Treaty. But the interplay of domestic and international factors during the ongoing discourse on the establishment of the $\mathrm{HQ}$ very much defined its future.

13 Herbert Smith Freehills LLP, "The Lisbon Treaty - brief overview of the key changes," European Union, November 4, 2009, accessed May 13, 2017, www.lexology.com/ library/detail.aspx?g=48a4327a-c5e8-41a7-8000-c93e90abe763.

14 Petersberg tasks were set out in the Petersberg Declaration adopted at the Ministerial Council of the Western European Union (WEU) in June 1992. On that occasion, the WEU member countries declared their readiness to make available to the WEU, but also to NATO and the EU, military units from the whole spectrum of their conventional armed forces. By now, the list of Petersberg tasks includes: humanitarian and rescue tasks; conflict prevention and peace-keeping task; tasks of combat forces in crisis management, including peacemaking; joint disarmament operations; military advice and assistance tasks; post-conflict stabilization tasks. http://eur-lex.europa.eu/summary/ glossary/petersberg_tasks.html. 
As Alistair Jones puts it, despite the fact that it was the Conservative government which brought Britain into the EEC in 1973, the Conservative Party has traditionally been Eurosceptic. ${ }^{15}$ Margaret Thatcher saw Britain's role as crucial within the Union and, for her, being 'inside' meant protecting British interests far more effectively. ${ }^{16}$ But, the leaders after Thatcher did not always see it that way. David Cameron, for example, is sometimes considered to be the most Eurosceptic leader of his party. This can easily be understood by the careful policies he developed towards CSDP.

David Cameron was very cautious about policy towards the EU from the very first day of taking the office. On the domestic level, he knew that majority of his party members were Eurosceptic and took care in avoiding the risk of losing domestic support. Indeed, the first factor of Putnam's theory that the size of the win-set depends on the domestic political institutions is demonstrated by Cameron's actions in avoiding being active on the EU level. He, therefore, avoided losing the support of the domestic institutions. Nevertheless, he still had to take into account the views of his pro-EU coalition partners and the active media discussion over Britain leaving the EU as major factors in any CSDP-related decisions.

Catherine Ashton, a British Labour politician, was the first High Representative of the EU for Foreign Affairs and Security Policy after the creation of the post according the Lisbon Treaty. She considered the creation of the HQ as being part of the implementation of the Lisbon Treaty. She was strongly supported by Germany and France in this view. But, she was just as strongly opposed by the British government. Consequently, the headquarters arrangements were not made. As Ashton commented, "This was to fulfill what the Lisbon Treaty was all about," she said. "The position of the British government is the same as the last government. It is not a blow, it was no surprise. It is important to put ideas on the table even if member states decide to reject them." 17

The Conservative Foreign Minister, William Hague, was concerned that Lady Ashton's initiative could give EU new security power, which would require additional finances in an era of big financial cuts and could also undermine NATO's role. After a row marking Britain's most serious rift with Lady Ashton, he warned that any mention of an EU military headquarters would trigger a British veto. ${ }^{18}$ So, although many EU member countries, including France, were very supportive of the initiative of creating an EU military $\mathrm{HQ}$, because of the British veto, it was never implemented.

15 Alistair Jones, Britain and the European Union (Edinburgh University Press, 2007).

16 Jones, Britain and the European Union, 27.

17 Bruno Waterfield, "Britain blocks EU plans for 'operational military headquarters'," The Telegraph, July 18, 2011, accessed March 20, 2017, http://www.telegraph.co.uk/ news/worldnews/europe/eu/8645749/Britain-blocks-EU-plans-for-operationalmilitary-headquarters.html.

18 Waterfield, "Britain," 28. 
Analysis of this case study shows the constant interplay between the domestic and international pressures which, in this case, did not bring to fruition the desired win-set for the EU. As in the first case study, we can argue that, while Britain was taking decisions over the creation of the EU operational headquarters, many factors, including developments within the EU, influenced Cameron. The EU was in the process of recovering from the post-2008 financial and economic crises and countries were hesitant to spend money on multilateral commitments; member states were resisting moves towards spending more on defense and security.

As with Saint-Malo, there was an ideological divide: the UK did not see the conceptual requirement for an EU military HQ. Instead, Britain was suggesting a cooperative approach, rather than creating this new institution. Hague's idea was to improve the links between existing national HQs. Simon Smith argues, “The UK's answer is always: we do not need one and there are plenty of military OHQs already in place in Europe. They will also say what type of military mission is so big that a national HQ cannot manage it? Or if it were, then NATO would most likely be involved anyway. Yet, this misses the need for CSDP to be able to do proper operational planning before a large crisis, especially combined civ-mil planning." 19

From a British perspective, the reasons for opposing the OHQ were financial and the need not to duplicate NATO's role in Europe. Preventing the decision against the operational headquarters can therefore be seen, for Britain, as a significant win-set achieved on the international level. Nor was this just a benefit to the UK. As Daniel Fiott points out,

Of course, why UK officials were really skeptical was finding the necessary political will and capacity in Europe to fund, man and use such a sizable OHQ. It was very hard to get member states to invest in capabilities at all, never mind for CSDP. The nations all ask, how much will it cost us if they get used? ${ }^{20}$

By that time, back in 2011, the EU was already running a series of overseas military missions and operations, such as a naval anti-piracy mission off the coast of Somalia and the Balkans peacekeeping mission, none of which seemed compromised by the lack of multinational $\mathrm{HQ}$. The British argument about the effectiveness of existing military operations being managed from a national $\mathrm{HQ}$ was based on the EUNAVFOR Atalanta, with the HQ in Northwood, UK.

19 Simon J. Smith, "European Defence, CSDP and the UK: two cases of catch-22," in The Common Security and Defense Policy: National Perspectives, ed. Daniel Fiott (Brussles: The Royal Institute for the International Relations, 2015), accessed February 17, 2017, http://aei.pitt.edu/64766/1/ep79.pdf.

20 Daniel Fiott, ed., The Common Security and Defense Policy: National Perspectives, EGMONT Paper 79 (Brussels: The Royal Institute for the International Relations, 2015), accessed March 15, 2017, http://aei.pitt.edu/64766/1/ep79.pdf. 


\section{Role of the United Kingdom in the Libyan Crisis (2011)}

In spring 2011, the president of Libya, Muammar Gaddafi, used force to suppress a popular revolt against his regime. The Libyan crisis was "one of the pieces of the broader puzzle of the Arab Spring," that spread with spillover effects through the Middle East and North Africa. ${ }^{21}$ In contrast to the previous two case studies, Britain's role in the Libyan crisis cannot be defined as a decision to support or block institutional developments of the CSDP. The crises over Libya in 2011 tested the CSDP and Britain, among other military powers of the EU, definitely had a role in this context.

France, in particular, found itself struggling to convince European partners to embark on military action. Because of the inaction and reluctance of the United States, Britain and France first focused efforts on getting the UN Security Council Resolution 1973 adopted. London and Paris seem to have considered that securing the UN mandate took priority over developing EU control of the Libyan operations. This might also be explained by the fact that they were both reluctant to surrender operational control to an EU body, preferring instead to rely on their respective air force chains of command.

For Britain, the win-set in the Libyan crisis was effective military involvement. The issue was a technical one: whether the operation would be under EU or NATO auspices. Cameron had domestic support: the Labour leader, Ed Miliband, gave full backing to military action and the House of Commons approved the military action by 557 votes to 13 . Anti-Gaddafi public opinion in Britain was already strong. Before the actual operation in Libya started, British oil workers in Libya had to be evacuated from an unfriendly situation. In addition, Gaddafi's security forces captured and beat up members of a BBC team and six members of one of the UK's elite special forces squadrons were allegedly captured and detained. 22

Cameron was mostly influenced by international factors because UK domestic opinion on intervening in Libya by the CSDP was not as problematic as it could have been. The positions of the EU member states were fragmented. Indeed, having specific relations with the Libyan Government over the oil deals made some member states reluctant to act. There was no united position on dealing with the crisis using EU's military capabilities. This controversy between the domestic and international levels very much influenced Cameron not to push for the CSDP to be involved. If, on the EU level, the member countries had had a consensus, meaning the big win-set, it could have positively affected the final decision and the outcome for the CSDP. But, on Libya that consensus was missing across the EU for various domestic reasons. Frustratingly, for CSDP purists, 20 years after the Balkan crises when CSDP was initiated, it must have seemed that

21 Maxime H.A. Larivé, Debating European Security and Defense Policy: Understanding the Complexity (Aldershot, Burlington: Ashgate Publishing Company, 2014), 209.

22 "Timeline: UK's road to action in Libya," BBC News, April 15, 2011, accessed April 2, 2017, http://www.bbc.com/news/uk-politics-12821505. 
the Libya crisis was the scenario for which CSDP had been created. As a result, the absence of a centralized command and control center of the EU itself became a reason for the limited possibility of acting rapidly. CSDP could not be the leading instrument; it was not institutionally in permanent readiness.

The Libyan intervention started on March 19, 2011, after the UN Security Council approved a "no fly zone" on March 17. The operation was conducted under the umbrella of NATO support, with Britain and France having the joint lead. This demonstrated that, even 20 years after the Balkan wars, Western Europe was incapable, on its own, of policing a no fly zone without NATO. ${ }^{23}$ As to the actual operation, together with the US, UK launched 12 Tomahawk missiles from one submarine off the Libya coast and contributed as well one Royal Air Force base. ${ }^{24}$ After this attack, articles appeared in the British press saying, for example: "Up to 20 per cent of the UKs Tomahawks has been used in the past four days in Libya, causing fears that it is burning through its armory." 25 In sum, a very small engagement on the borders of Europe had exposed the fragility of Britain's defense capabilities, a point that reinforced its skepticism about multinational command and control of operations. Nor was Britain alone in this. The response that the EU gave to the Libya crisis was a demonstration of the fact that EU could not process its military and defense capabilities within a multinational framework without an EU consensus. This was summed up by the International Institute for Security Studies thus: "They have shown the emptiness of claims that the Lisbon Treaty of 2009 could make the EU better fitted to take action than it was during the crises of the Balkans." 26

Addressing the UK elements of the win-set, from Putnam's Two-Level Game Theory, it can be said that the win-set in the Libya crises depended on both domestic and international factors. Cameron did not have to struggle much on a domestic level. But still, domestic factors were involved in the interplay with the EU - which itself did not have a united position on the intervention via CSDP. If the EU had had a strong position, the outcome of CSDP involvement would probably have been different. We can conclude that during the negotiations the outcome depended on the size of the win-set, the bigger win-set being successful. So, if EU could have had the bigger win-set, meaning having consensus between the members states on intervention in Libya, the last win-set, the inter-

23 It is useful to recall that Germany abstained in the UN security Council on the matter of Libyan no fly zones.

24 Thomas Harding, "Libya: Navy running short of Tomahawk missiles," The Telegraph, March 23, 2011, accessed April 5, 2017, http://www.telegraph.co.uk/news/ worldnews/africaandindianocean/libya/8400079/Libya-Navy-running-short-ofTomahawk-missiles.html.

25 Harding, "Libya," 32.

26 "War in Libya: Europe's confused response," The International Institute for Security Studies, Volume 17, Comment 18, April 2011, accessed February 28, 2017. http://deps.panteion.gr/images/Libya-Europe-confused-response.pdf. 
vention itself could be different, because EU's common decision could have influenced Britain's position as well.

It is reasonable to conclude that, even in the cases when Britain does not have radically positive or radically negative positions towards CSDP, the interplay between the domestic and international factors still applies. In the Libyan case, intervening via CSDP was not the win-set for Britain-the win-set was the intervention itself-but it was not the same win-set for the CSDP/EU, which had its problems of policy incoherence in this instance.

\section{Conclusion}

The three case studies help to answer the research question, "Why did Britain back the launch of the CSDP but did not then consistently support all its developments?" The interplay between domestic and international levels is evident in the all three case studies, but the level of controversy between them is different. We can say that Britain has never had a strong political pro-European movement unlike the other EU member countries. The membership of the EU was important to Britain without having to play a full part in it. In the UK's Strategic Defense and Security Review 2015, there is not a single reference to Britain's role in the CSDP. ${ }^{27}$ Some scholars interpreted this as Britain ignoring the Common Security and Defense Policy, thinking separately of its challenges and opportunities through the timeline of being part of it. Certainly, in Britain's positions towards CSDP there has always been an interplay between domestic and international factors. It is safe to assume that the Putnam concept of the win-set, in general, helps to explain Britain's domestic and foreign policy approaches to CSDP.

The first case study, launching the CSDP, is an example how Britain was pushing towards CSDP. Britain's role in the CSDP has been abundantly discussed after the Europe's attempt to develop autonomy in the security and defense spheres. The Saint-Malo Declaration was signed in December 1998 by British Prime Minister Tony Blair and French President Jacques Chirac, who met to advance the creation of a European Security and Defense Policy, including a European military force capable of autonomous action. The Saint-Malo declaration was a response to the armed conflict in Kosovo in the late 1990s, in which the international community, and especially the European Union and its member states, were perceived to have failed to intervene to stop the conflict. The fact that British Government was pushing for the EU's Security and Defense policy was taken by a wide range of scholars as Britain's initiative to lead CSDP. This first case study is the demonstration of the first factor of the win-set, Britain was very much for strengthening EU's defense capabilities and it had consensus at the domestic level as well. The decision made in Saint-Malo was influenced for

27 “National Security Strategy and Strategic Defence and Security Review 2015," Policy Paper (UK Government, November 23, 2015), accessed April 10, 2017, https://www.gov.uk/government/publications/national-security-strategy-andstrategic-defence-and-security-review-2015. 
Britain by both domestic and EU developments, reflecting Putnam's parallel levels game theory.

The second case study, between 2010-11, showed Britain blocking operational development and the establishment of an $\mathrm{HQ}$, has a different outcome but the theory remains applicable from the UK side. The creation of the Operational Headquarters had become one of the major issues of the EU-British relationships after the David Cameron's Conservative party took office. Catherine Ashton considered the creation of the HQ "was to fulfill what the Lisbon Treaty was all about." ${ }^{28}$ This case study is analyzed by the second factor of the win-set, where success of win-set depends on the strategies of the negotiator on the international level; the win-set for the David Cameron's traditionally Eurosceptic government was to block the creation of the operational Headquarters for the EU again, this decision was influenced both by domestic politics in Britain and developments within the EU.

The third case study, which concentrated on Britain's role in the Libyan crisis, is not traditionally about the role of the CSDP in institutional development, but it is more about the chance of the CSDP to be tested in a real-life scenario and about Britain and others indirectly undermining it. On the domestic level, Cameron did not meet opposition to military involvement in the crisis, but on the EU and wider international level, there were contrary factors that defined Britain's position. First, the EU members were not of one mind on Libya; CSDP was always going to be a difficult instrument to use. Secondly, the UK preferred a bilateral involvement with France. Thirdly, there was the natural bias towards NATO which, with France, is also why the operation was carried out under the NATO umbrella. One can argue, for France, it was generally an ideological matter to prefer the idea of the strong and united Europe but for the Libyan crisis the necessary agreement was not in place across the EU. For Britain, the issue of leadership in the Libyan operation was purely technical. There was a decision to be involved, but it was not one to be involved via CSDP. Britain never believed in the military capabilities of the EU. Previous case studies show that even when supporting the idea of CSDP, it was very much the result of developments within the EU and the USA and fell well short of a wholehearted commitment by Britain.

This article and applied theoretical framework gives food for thought about the future of both Britain and the CSDP. In general, we could see CSDP as the future of the EU's global security. It is clear that Britain cannot avoid military cooperation with EU member states. Perhaps post-Brexit, conditions will make cooperation even closer. Our research shows that Britain never felt comfortable sharing military independence on the multilateral level other than within NATO. But NATO is a different case, everyone agrees that USA has the leadership of the organization and, having historically varied but usually close ties with the US, Britain is considered to be the European ally of Washington within NATO.

28 Waterfield, "Britain," 28. 
After the Brexit decision, Britain was accused of 'paralyzing' CSDP by the German Minister of the Defense. ${ }^{29}$ However, this may be a superficial judgement. Things have traditionally worked better on a bilateral level. Therefore, in the next five years, we may see different forms of cooperation based on the concept of 'plus' - it can be Britain plus US; Britain plus EU; Britain plus member countries; and Britain plus extra-European countries as well. As for the CSDP, many scholars argue that Brexit gives a momentum to the EU to breathe new life into its security and defense policy. An additional factor is the United States and President Donald Trump, who, by his statements, appears to be reluctant to assist in European Security. Perhaps this, more than any other single factor, will be the catalyst for the CSDP to blossom - at last.

\section{About the Author}

Irina Tsertsvadze is Head of EU Integration and Relations with the International Organizations Division, Ministry of Defense of Georgia since May 20015. Prior to this, she worked at the Parliament of Georgia, Committee on European Integration, where she was leading the cooperation with the International Organizations, local NGOs and Media Outlets. Her background includes five years working as an international journalist in Moscow, Russia, as a Georgian Public Broadcasters correspondent (2007-2008) and International Broadcaster at VOA Georgian Service, Washington DC, USA (2009-2010). She holds a BA in International Journalism from Tbilisi State University, Specialist Diploma in TV Journalism from Moscow State University and MAS in International and European Security from the University of Geneva. Irina is alumni of George C. Marshall European Center for Security Studies and was GCMC Fellow of 2014. She is also a fellow of CBGL program at Georgian Foundation of Strategic and International Studies of 2012. Currently Irina is PhD student at Ilia State University, Tbilisi, Georgia. Irina is fluent in Georgia, English and Russian.

29 Daniel Keohane, “Can France and Germany lead European Defence?" Europe's World, accessed April 12, 2017, http://www.friendsofeurope.org/publication/can-franceand-germany-lead-european-defence. 